\title{
STUDIES UPON THE MECHANISM OF RESERPINE- INDUCED ARREST IN EGG TRANSPORT IN THE MOUSE OVIDUCT
}

\section{COMPARATIVE EFFEGTS OF SOME AGENTS WITH ACTIONS ON SMOOTH MUSCLE AND TISSUE AMINES}

\author{
K. E. KENDLE AND J. P. BENNETT* \\ B.D.H. (Research) Ltd, Borough Road, Godalming, Surrey
}

(Received 19th October 1968)

\begin{abstract}
Summary. The position of eggs in the reproductive tract of the mouse was determined following the administration of several drugs with effects on smooth muscle and tissue amines. Of the compounds examined, only chlorpromazine and tetrabenazine were effective in causing a reduction in the rate of egg transport in the oviduct. Both compounds, like reserpine, caused hypothermia in the mouse. Further investigation showed that the arrest of egg transport can be prevented by housing animals at elevated environmental temperatures. The implications of these findings in relation to the physiology of the mouse oviduct are discussed.
\end{abstract}

\section{INTRODUCTION}

Adrenergic nerve fibres have been demonstrated in the oviduct of the rabbit (Brundin, 1965), man (Brundin \& Wirsen, 1964) and rat (Norberg \& Fredricsson, 1966). Sympathomimetic drugs have been shown to produce strong contractions in the rabbit oviduct (Joshi \& Asdell, 1966), and Nakanishi \& Wood (1968) have shown changes in the muscle tone of the human oviduct in vitro caused by adrenergic blocking drugs. Despite these observations, few investigations have been concerned with the relationship between pharmacological agents which alter autonomic or smooth muscle activity and egg transport rate.

Bennett \& Kendle (1967) observed arrest of egg transport in the mouse oviduct following treatment with reserpine, a tranquillizing and hypotensive agent, and further investigations (Kendle \& Bennett, 1969) indicated that changes in hormone secretion are not solely responsible for this action of reserpine.

The possible rôle of central and peripheral depletion of tissue amines in this phenomenon has now been examined by a comparison of the effects of other drugs with those of reserpine.

* Present address: Institute of Hormone Biology, Syntex Research Centre, Palo Alto, California, U.S.A. 


\section{MATERIALS AND METHODS}

The conditions under which specific pathogen-free albino mice were maintained and mated have already been described (Kendle \& Bennett, 1969). The mated animals were distributed daily between the various groups. In each experiment, a range of dose levels of the drug was given to groups of mated mice while a group of control animals was given the dose vehicle by the appropriate route.

Tetrabenazine and $p$-chlorophenylalanine were prepared as aqueous suspensions in a medium containing $1.2 \% \mathrm{w} / \mathrm{v}$ carboxymethyl cellulose and $1.5 \% \mathrm{w} / \mathrm{v}$ Tween 80 . The remaining compounds were dissolved in water. The dose volume was adjusted to $10 \mathrm{ml} / \mathrm{kg}$ body weight. The compounds were given by the subcutaneous or intraperitoneal route, the former being chosen when the biological half-life of the drug was known or suspected to be relatively short.

At each dose level, five mated mice were given one dose of the compound on the 1st day of pregnancy, and killed on the 2nd day, while a further five animals were given three consecutive daily doses on Days 1, 2 and 3 and killed on Day 4. As guanethidine is known to produce a prolonged depletion of peripheral catecholamines following a single dose (Porter, Totaro \& Stone, 1963), five animals were killed on Day 2 of pregnancy and a further five on Day 4 following a single dose of this compound given on Day 1. The oesophageal temperature of each animal was recorded immediately before killing, using a thermocouple thermometer (Ellab, Elektro Laboratories, Copenhagen). At autopsy, the positions of the eggs within the reproductive tract were determined as previously described (Kendle \& Bennett, 1969).

In a further series of experiments, mated mice were given $4 \mathrm{mg} / \mathrm{kg}$ of reserpine by the intraperitoneal route on the 1st day of pregnancy. The solution of reserpine was prepared as described previously (Bennett \& Kendle, 1967). The animals were housed as before except that they were placed in cabinets permitting adjustment of the environmental temperature. Various groups of animals were kept in environmental temperatures of $26,30,33$ and $36^{\circ} \mathrm{C}$ and ten animals from each group were killed on Days 2, 3 and 4 of pregnancy. A control group of ten animals given $4 \mathrm{mg} / \mathrm{kg}$ reserpine on Day 1 of pregnancy was kept at $22^{\circ} \mathrm{C}$ until autopsy on Day 4 . Oesophageal temperatures were recorded immediately before killing, and the position of eggs within the reproductive tract determined as before.

Two further groups of five mice were given chlorpromazine and tetrabenazine on Days 1 to 3 of pregnancy while being kept at an environmental temperature of $33^{\circ} \mathrm{C}$. These animals were killed on Day 4 of pregnancy and the position of eggs within the reproductive tract was determined.

\section{RESULTS}

The principal pharmacological activities of the compounds studied and their effect upon the rate of egg transport are shown in Table 1. Apart from reserpine (Bennett \& Kendle, 1967), only tetrabenazine and chlorpromazine reduced the rate of egg transport in the mouse oviduct. Table 2 shows the effect of various doses of tetrabenazine upon the position of the eggs in the genital tract on Day 4 of pregnancy. The mean oesophageal temperatures of the animals immediately 
TABLE 1

EFFECT UPON EGG TRANSPORT IN THE MOUSE OF VARIOUS DRUGS HAVING KNOWN EFFECTS UPON THE AUTONOMIC NERVOUS SYSTEM

\begin{tabular}{|c|c|c|}
\hline Compound & Principal pharmacological activity & $\begin{array}{l}\text { Effects upon } \\
\text { rate of egg transport }\end{array}$ \\
\hline Reserpine & $\begin{array}{l}\text { Depletion of central and peripheral catechol- } \\
\text { amines and } 5-\mathrm{HT}^{*} \text {. Hypothermic }\end{array}$ & Retardation or arrest \\
\hline Tetrabenazine & $\begin{array}{l}\text { Depletion of catecholamines and } 5 \cdot \mathrm{HT} \text { mainly } \\
\text { in CNS. Hypothermic }\end{array}$ & Retardation or arrest \\
\hline Guanethidine & Depletion of catecholamines peripherally & None \\
\hline$p$-Chlorophenylalanine & $\begin{array}{l}\text { Depletion of central and peripheral 5-HT by } \\
\text { blocking synthesis }\end{array}$ & None \\
\hline Chlorpromazine & $\begin{array}{l}\text { Weak blockade of } \alpha \text {-adrenergic receptors, } \\
\text { depletion of peripheral } 5 \text {-HT with alteration } \\
\text { in central turnover. Hypothermic }\end{array}$ & Retardation or arrest \\
\hline Rogitine & Blockade of $\alpha$-adrenergic receptors & None \\
\hline Amphetamine & $\begin{array}{l}\text { Weak blockade of } \alpha \text {-adrenergic receptors, CNS } \\
\text { stimulant }\end{array}$ & None \\
\hline Pronethalol & Blockade of $\beta$-adrenergic receptors & None \\
\hline Dichloroisoprenaline & Blockade of $\beta$-adrenergic receptors & None \\
\hline Atropine & $\begin{array}{l}\text { Blockade of cholinergic receptors. Higher doses: } \\
\text { blockade of all autonomic ganglia }\end{array}$ & None \\
\hline
\end{tabular}

* 5-HT = 5-hydroxytryptamine.

before autopsy are also shown. The lowest dose of tetrabenazine which produced unequivocal reduction in the rate of egg transport was also the lowest dose which caused profound hypothermia. The compound had no effect upon the number of eggs recovered. The development of the eggs was, however, retarded by doses of 200 to $400 \mathrm{mg} / \mathrm{kg} /$ day; in these treatment groups, they were at the one- or two-cell stages, in contrast to the late morulae or early blastocysts observed in control animals. The effect of various doses of chlorpromazine upon the rate of egg transport and oesophageal temperature is shown in Table 3. As in the case of tetrabenazine and reserpine, the development of the eggs,

\section{TABLE 2}

EFFECT OF TETRABENAZINE UPON THE RATE OF EGG TRANSPORT AS INDICATED BY THE MEAN \% OVIDUCT TRAVERSED ON DAY 4 OF PREGNANCY IN GROUPS OF FIVE MATED MICE TREATED ON DAYS 1 TO 3

\begin{tabular}{|c|c|c|c|}
\hline Dose $(\mathrm{mg} / \mathrm{kg})$ & $\begin{array}{l}\text { Mean } \% \text { oviduct } \\
\text { traversed } \pm S . E .\end{array}$ & $\begin{array}{l}\text { Mean no. } \\
\text { eggs recovered }\end{array}$ & $\begin{array}{c}\text { Mean oesophageal } \\
\text { temperature }\left({ }^{\circ} C\right) \pm S . E .\end{array}$ \\
\hline - & $\begin{array}{l}100+(79 \% \text { eggs })^{*} \\
72 \pm 0.5(21 \% \text { eggs })\end{array}$ & $\begin{array}{l}6 \cdot 8 \\
1.8\end{array}$ & $38.4 \pm 0.21$ \\
\hline 50 & $100+$ & $8 \cdot 6$ & $38 \cdot 4 \pm 0 \cdot 15$ \\
\hline 100 & $\begin{array}{l}100+(36 \% \text { eggs }) \\
86 \pm 1(64 \% \text { eggs })\end{array}$ & $\begin{array}{l}3 \cdot 2 \\
5 \cdot 8\end{array}$ & $36 \cdot 3 \pm 0.55$ \\
\hline 200 & $43 \pm 4$ & 8.0 & $28 \cdot 6 \pm 1 \cdot 28$ \\
\hline 400 & $43 \pm 1$ & $9 \cdot 6$ & $28.8 \pm 0.54$ \\
\hline
\end{tabular}

* The symbol $100+$ is used to represent the position of eggs recovered from the uterus. 
TABLE 3

EFFECT OF CHLORPROMAZINE UPON THE RATE OF EGG TRANSPORT AS INDIGATED BY THE MEAN PERGENTAGE OVIDUCT TRAVERSED ON DAY 4 OF PREGNANCY IN GROUPS OF FIVE MICE TREATED ON DAYS 1 TO 3

\begin{tabular}{c|c|c|c}
\hline Dose $(\mathrm{mg} / \mathrm{kg})$ & $\begin{array}{c}\text { Mean \% oviduct } \\
\text { traversed } \pm \text { S.E. }\end{array}$ & $\begin{array}{c}\text { Mean no. } \\
\text { eggs recovered }\end{array}$ & $\begin{array}{c}\text { Mean oesophageal } \\
\text { temperature }\left({ }^{\circ} \mathrm{C}\right) \pm S . E .\end{array}$ \\
\hline$\overline{2}$ & $100+^{*}$ & $9 \cdot 6$ & $39 \cdot 0 \pm 0 \cdot 02$ \\
20 & $100+$ & $8 \cdot 0$ & $38 \cdot 2 \pm 0 \cdot 06$ \\
\hline & $37 \pm 3 \cdot 13$ & $8 \cdot 2$ & $31 \cdot 0 \pm 2 \cdot 75$ \\
\hline
\end{tabular}

* The symbol $100+$ is used to represent the position of eggs recovered from the uterus.

which ranged from the one- to eight-cell stage, was also retarded following a dose of $20 \mathrm{mg} / \mathrm{kg} /$ day chlorpromazine.

Text-figure 1 shows the effect upon the rate of egg transport of keeping reserpine-treated animals in elevated environmental temperatures. Even an elevation of $4^{\circ} \mathrm{C}$ caused some reversal of the complete arrest of egg transport observed when the treated animals were maintained at $22^{\circ} \mathrm{G}$. An environmental temperature of $36^{\circ} \mathrm{C}$ produced a transport pattern which is apparently normal. It was observed at autopsy that the eggs within the reproductive tracts of mice housed at $36^{\circ} \mathrm{C}$ were at the same stage of development as would be expected in control animals killed on the same day of pregnancy.

The minimum environmental temperature $\left(36^{\circ} \mathrm{C}\right)$ which completely pre-

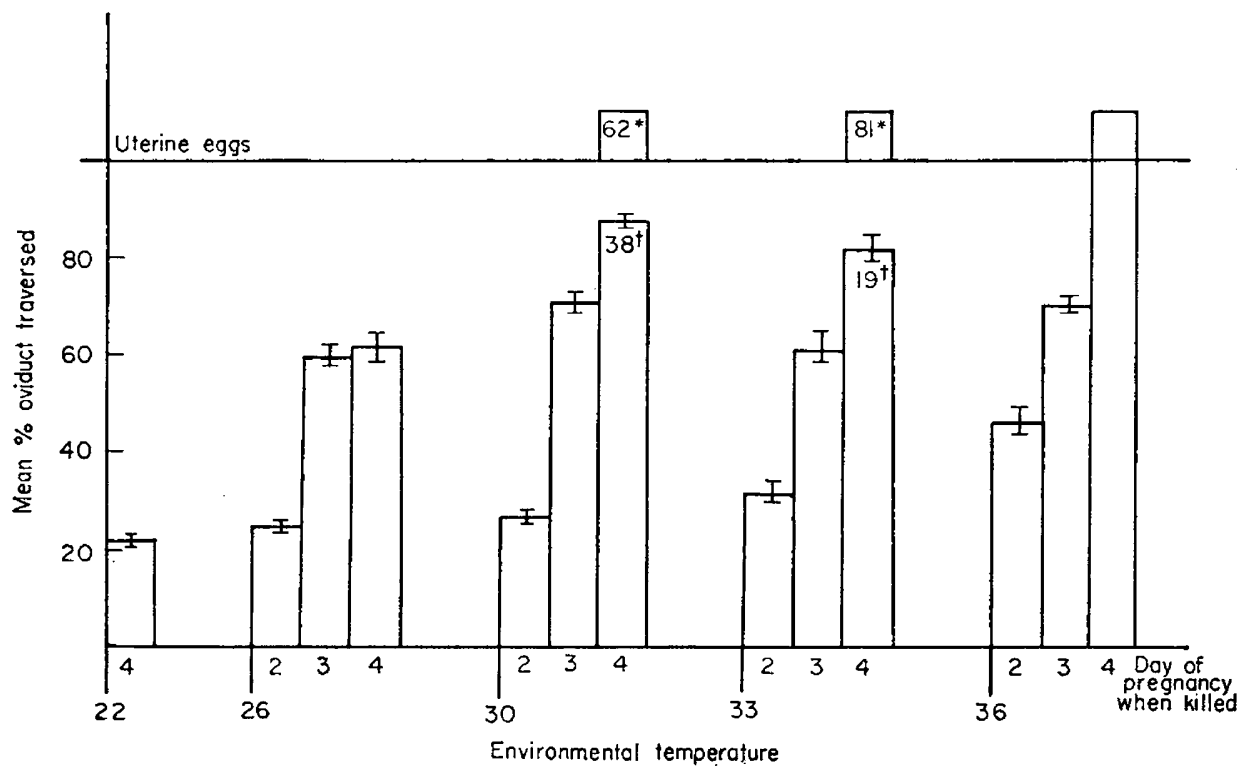

TexT-FIG. 1. The rate of egg transport in groups of ten mated mice given $4 \mathrm{mg} / \mathrm{kg}$ reserpine on Day 1 of pregnancy and maintained at various environmental temperatures.

* Percentage of total eggs recovered from uterus.

$\dagger$ Percentage of total eggs observed in the oviduct. 
vented retardation of egg transport and development was also the minimum which prevented the lowering of body temperature by reserpine on any day of autopsy.

Similarly, $83 \%$ of the eggs were found in the uterus on Day 4 of pregnancy in a group of mice given $200 \mathrm{mg} / \mathrm{kg} / \mathrm{day}$ tetrabenazine, when these were maintained in an environmental temperature of $33^{\circ} \mathrm{C}$. Normal numbers of blastocysts were recovered from the uteri of animals given $200 \mathrm{mg} / \mathrm{kg} /$ day chlorpromazine (a dose which is in excess of its $\mathrm{LD}_{100}$ at $22^{\circ} \mathrm{C}$ ) when they were housed at $33^{\circ} \mathrm{G}$ until autopsy on Day 4 .

\section{DISCUSSION}

The presence of adrenergic nerves in the oviducts of several species and the action of catecholamines upon muscular activity of the oviduct suggest that the rate of egg transport may be controlled, in whole or in part, by sympathetic innervation. The activity of reserpine in causing arrest of egg transport in the mouse is compatible with this suggestion, since depletion of catecholamines from stores at peripheral sympathetic nerve endings is one of the many known effects of this drug, as cited previously (Porter et al., 1963; Bennett \& Kendle, 1967).

It has, however, been shown that high dose levels of both $\alpha$ - and $\beta$-adrenergic blocking agents, namely rogitine, dichloroisoprenaline and pronethalol, were without effect upon the rate of egg transport, and doses of atropine which were adequate to block autonomic ganglia were similarly without effect. These results suggest that sympathetic innervation does not control the rate of egg transport in the mouse, though it may be argued that the biological half life of these compounds is too short for any effects on the musculature of the oviduct to alter the rate of egg transport, despite the subcutaneous injection of massive doses. Guanethidine produces a profound and prolonged depletion of peripheral catecholamine stores in many species (Cass, Kuntzman \& Brodie, 1960; Cass \& Spriggs, 1961), including the mouse (Porter et al., 1963), but was without effect upon the rate of egg transport. These findings indicate that, in the mouse, the activity of the sympathetic nervous system plays no rôle in the control of the rate of egg transport through the oviduct and that the observed effect of reserpine is not due to depletion of peripheral catecholamine stores.

Low doses of atropine block transmission at cholinergic parasympathetic nerve endings. The inactivity of this compound would, therefore, indicate that the parasympathetic nervous system also has no part in the control of egg transport in the mouse. This is supported by our hitherto unreported observations that acetycholine only induces very feeble contractions of the cannulated perfused rabbit oviduct in vivo.

The results summarized in Table 1 indicate that tetrabenazine, like reserpine, is effective in arresting egg transport in the mouse oviduct. As with reserpine, this compound causes depletion of catecholamines and 5-hydroxytryptamine, but its effects are predominantly on the central nervous system (Haggendal, 1968). This would suggest that central effects may be responsible for the action of reserpine on egg transport. Similarly, chlorpromazine was effective in 
arresting egg transport but amphetamine was not. While both compounds have weak $\alpha$-adrenergic blocking activity, chlorpromazine interferes with the turnover of central biogenic amines (Gey \& Pletscher, 1961) and amphetamine is a CNS stimulant. Thus, the pharmacological activities common to the effective compounds, reserpine, tetrabenazine and chlorpromazine, are interference with centrally acting 5-hydroxytryptamine and catecholamine turnover and hypothermic activity.

The compound $p$-chlorophenylalanine, a depleter of brain 5-hydroxytryptamine (Koe \& Weissman, 1966; Somerville \& Whittle, 1967), is neither hypothermic nor effective in arresting egg transport. A possible explanation of these findings lies in the fact that $p$-chlorophenylalanine produces depletion by blocking synthesis of 5-hydroxytryptamine. In contrast, the hypothermic agents alter turnover and it may be some aspect of the free 5-hydroxytryptamine levels in the CNS which causes hypothermia in the mouse.

The experiments conducted at elevated environmental temperature show a causal relationship between hypothermic activity and egg transport, since prevention of a fall in body temperature also completely inhibits the druginduced arrest of egg transport. This finding suggests that the various endocrine (Kendle \& Bennett, 1969) and peripheral activities of reserpine are without effect upon egg transport mechanisms.

Since the arrest of egg transport by the hypothermic agents was never accompanied by loss of eggs or any indication of accelerated transport, it seems likely that the effect is due to reduced muscular activity in the oviduct. This contrasts with the effects of oestrogens which can produce tube locking or accelerated transport probably due to a state of hyperactivity of the muscle (Humphrey, 1968).

\section{REFERENCES}

Bennett, J. P. \& Kendle, K. E. (1967) The effect of reserpine upon the rate of transport in the Fallopian tube of the mouse. F. Reprod. Fert. 13, 345.

BRUndin, J. (1965) Distribution and function of adrenergic nerves in the rabbit Fallopian tube. Acta physiol. scand. 66, Suppl. 259.

Brundin, J. \& Wirsen, C. (1964) Adrenergic nerve terminals in the human Fallopian tube examined by fluorescence microscopy. Acta physiol. scand. 61, 505.

CAss, R., Kuntzman, R. \& Brodie, B. B. (1960) Norepinephrine depletion as a possible mechanism of action of guanethidine, a new hypotensive agent. Proc. Soc. exp. Biol. Med. 103, 871.

Cass, R. \& Spriggs, T. L. B. (1961) Tissue amine levels and sympathetic blockade after guanethidine and bretylium. Br. F. Pharmac. Chemother. 17, 442.

Gey, K. F. \& Pletscher, A. (1961) Influence of chlorpromazine and chlorprothixine on the central metabolism of 5-hydroxytryptamine, norepinephrine and dopamine. 7. Pharmac. exp. Ther. $133,18$.

HAGgendal, J. (1968) The depletion and recovery of noradrenaline in the brain and some sympathetically innervated mammalian tissues after tetrabenazine. F. Pharm. Pharmac. 20, 364.

Humphrey, K. W. (1968) The effects of oestradiol-3,17 $\beta$ on tubal transport in the laboratory mouse. 7. Endocr. 42, 17.

Joshi, S. R. \& Asdell, S. A. (1966) Pharmacology of the rabbit oviduct. Fedn Proc. Fedn Am. Socs exp. Biol. 25, 444.

Kendle, K. E. \& Bennett, J. P. (1969) Studies upon the mechanism of reserpine-induced arrest of egg transport in mouse oviduct. I. The effect of hormone replacement. F. Reprod. Fert. 20, 429.

KoE, B. K. \& Weissman, A. (1966) Marked depletion of brain serotonin by $p$-chlorophenylalanine. Fedn Proc. Fedn Am. Socs exp. Biol. 25, 452.

Nakanishi, H. \& WOOD, C. (1968) Effects of adrenergic blocking agents on human Fallopian tube motility in vitro. J. Reprod. Fert. 16, 21. 
Norberg, K. A. \& Fredricsson, B. (1966) Cellular distribution of monoamines in the uterine and tubal walls of the rat. Acta physiol. scand. 68, Suppl. 277.

Porter, C. C., Totaro, J. A. \& Stone, C. A. (1963) Effect of 6-hydroxydopamine and some other compounds on the concentration of norepinephrine in the hearts of mice. 7. Pharmac. exp. Ther. $140,308$.

Somervilie, A. R. \& Whittle, B. A. (1967) The interrelation of hypothermia and depletion of noradrenaline dopamine and 5-hydroxytryptamine from brain by reserpine, $p$-chlorophenylalanine and methylmetatyrosine. Br. F. Pharmac. Chemother. 31, 120. 